\title{
PROTECTION OF APPLICABLE INVENTION PATENT LAW BASED ON THE TRACTS OF PATENT COOPERATION IN THE COMPUTER FIELD
}

\author{
Andika Carsya Nafebra \\ 185100012P \\ Fakultas Komputer, 448757196 \\ andikacarsyanafebra.student@umitra.ac.id
}

\begin{abstract}
Very rapid technological development, especially in the field of computers resulted in form legal protection not only through patent protection against hardware but also patents on computer programs. Developments in developed countries have a tendency to patent protection that reaches protection against the formulation of algorithms even programming languages as supporting parts of computer programs such as Extensible Markup Language (abbreviated as XML), while in Indonesia, computer programs themselves are not objects of patent protection. Based on this, the author conducted a research in the form of a thesis with the aim to determine whether Extensible markup language can be an object protected by a patent based on Law No. 14 of 2001 concerning Patents in Indonesia in the case of an XML Patent registered in the United States registered with number 5,787,449 which has just become a dispute in the court in the United States between i4i and Microsoft and how it impacts after a verdict has stated that there has been a violation of an XML patent in another country ... The method used in this research is analytical descriptive method with a normative legal approach. the research conducted was library research and supported by field research through interview instruments. A Programming Language such as Extensible Markup Language cannot be an object that is protected by a Patent Law in Indonesia, the only protection for XML is indirectly protected by Patents, namely through the Treaty of the SamaPaten based on Presidential Decree No. 16 of 1996 where patents can be registered for regional protection fellow WIPO member countries. The existence of a computer program with the extensible markup language feature that has violated patents in the United States in relation to Presidential Decree Number 16 of 1997 in Indonesia does not have executorial power as it applies statelimited patents, except that XML has been registered through PCT Patent protection against XML is possible. By considering priority rights which are limited to retroactive conditions when the patent registration is first registered at least in one other country outside Indonesia.
\end{abstract}

Keywords: Algorithms, Patents, Software, XML. 


\section{INTRODUCTION}

\subsection{Background}

The field of technology has become an important point in the progress of a nation in competition both economically and politically domination. Various inventions of a technology can also determine the effectiveness of an economic activity. Historically, the development of industries in Europe included the use of machinery in place of human power and as a result of encouraging developers or inventors of intellectual work which at first originated from advanced industrial countries hoping for protection for their creation, the international community held a meeting that then produced the Paris Convention for the Protection of Industrial Property (Paris Convention) on March 20, 1883 in Paris, France. The Paris Convention has undergone several changes and most recently in Stockholm in 1979 and in 2002 there were 163 (one hundred and sixty three) countries

[1]. The Paris Convention principally regulates industrial property rights which include patents (inventions), models and designs (utility models), industrial designs (industrial designs), trademarks (trademarks), trade names (trade names), and fraudulent competition (unfair competition).

In 1886 another international agreement was formed, providing Copyright protection with the enactment of the Berne Convention for the Protection of Literary and Artistic Works (Berne Convention) which until 2002 had 105 (one hundred and five) members. In principle, what is regulated in the Berne Convention is that copyright concerns literary and artistic works, including all works produced in the fields of literature, art and science. The basic principle of copyright protection according to the Berne Convention is protection of works, where ideas are not protected until the idea becomes a reality

[2] The United Nations (UN) then formed an international institution to deal with issues of Copyright and other rights related to industry called the World Intellectual Property Organization (WIPO) on July 14, 1967 in Stockholm.

Convention

[3] WIPO itself comes from Paris Convention and Berne

[4]. One of the fields discussed in the Paris Convention regarding the development of industry which is very identical to the development of machine machines, especially computerization of various industries. Computer development can also be said to be one of technological developments, in connection with the use of this technology there is a term known as patent. A patent is a special right that is owned by an inventor or another person who is entitled by the inventor to carry out an invention himself or give permission to others to carry out the invention. 


\subsection{The concept of IPR on computer programs}

The basic concept in appreciating and developing research results cannot be separated from the treatise on the construction of legal protection for the creativity and productivity of human technology. This concept can be traced from Lockean teachings, which is a philosophical foundation for the validation of the existence of a creativity that is currently known as IPR. The basic conception of intellectual property rights (HKI) based on propositions postulated by John Locke include:

"(1) God has given the world to people in common;

(2) Every person has a property in his own person;

(3)A person 's belong to him;

(4) Whenever a person mixes his labor with something in the commons, hethereby makes it his property;

(5) The rights of property is conditional upon a person leaving in thecommons enough and as a good for the other commoners;

(6) A person cannot take more out of thecommons than they can use to advantage"

In general, the Free Computer Program and the Proprietary Computer Program as mentioned earlier are protected by Copyright because in the Copyright Law it is stated "Computer Program" as the object of Copyright protection without any specific categorization. If you look at the context of copyright protection on this computer program in broad outline, that every use, multiplication / duplication and announcement of a computer program must obtain permission from the copyright holder for the computer program. In the patent the special rights are given by the state to the inventors in their technological findings, for a certain period of time carrying out the invention itself or giving approval to others to use it. The discovery must have an element of novelty. Article 27 (1) TRIPs have explained that the patent subject can be applied to any invention, whether products and manufacturing processes in the field of technology, meet new elements, and there are steps that can be applied to industrial activities. It is also formulated in Article 7 of Law Number 13 Year 1997 in conjunction with Article 7 of Law Number 14 Year 2001 concerning patents, which extends patent protection for all types of inventions in the field of science. The WorldIntel lectual PropertyOrganization (WIPO), providesadefinitionThe patent is as follows: "A patent is enforced rightrights grantedbythe law of a person to exclude, for a limitedtime, others fromcertain acts in relation to new invention; the privilege is granted by a government authority as a matter of right to the personwho is entitled to apply for it and who fulfills the prescribed conditions "[6]. While things that cannot be granted a patent include:

a. Findings about the process or production results of the invention and its implementation are contrary toapplicable legislation, public order or decency;

b. Findings about methods of examination, treatment and surgery that are applied to humans and animals, but do not reach any product used or related to the method.

c. Discovery of theories and methods in the field of science and mathematics. 


\section{PROTECTION OF COMPUTER PROGRAMS IN INDONESIA}

The concept of patents in Indonesia places exclusive rights as the core of patent rights. It is a monopoly right limited to the technology described in patent documents, to inventors who first publish their inventions that contribute to technological and industrial progress. It offers a monopoly to the developer of a useful product or process. More precisely, patents are exclusive rights or legal rights to prevent third parties from making, using, or selling any inventions constructed in a patent claim. Substantially, the exclusive right is given by the state to the inventor to carry out his invention or give authority to others to carry it out in a certain period of time.

This exclusive right includes the principle of patent names that provide legal protection for inventors or patent holders to carry out their findings within a period of 20 years for standard patents and 10 years for simple patents. The latest patent arrangement discussion in the Patent Law Number 14 of 2001 gives an understanding as the following: Exclusive rights granted by the state to inventors for the results of their inventions in the field of technology, which for a certain period of time carry out their own inventions or give their consent to other parties to implement them." Thus, other people are prohibited from carrying out patents. the right to exploit the invention, the patent owner is also given the right to transfer patent rights to other parties. The patent owner is also given the right to give licenses to other parties through a license agreement. Other parties who receive the transfer of patent rights then become patent holders who also have exclusive rights to exploit the invention.Patents can be transferred to other parties in whole or in part by: inheritance,grants, wills, written agreements (licenses), or other reasons justified by statutory regulations (for example due to the dissolution of a legal entity that was originally a patent holder), Indonesia, Patent Law, Article. 66 paragraph (1) and the explanation.

A license is a permit granted by a patent holder to another party based on an agreement granting the right to enjoy economic benefits from a patent that is given protection in a period of time and certain conditions, Ibid., Article. 1 term 13. Licenses granted may be exclusive licenses, single licenses, or non-exclusive licenses

a. Exclusive license is a license granted to certain parties, and the original rights holder is not entitled to carry out his invention.

b. A single license is the holder of the patent to transfer his patent to another party, but the patent holder still has the right to exercise his rights.

c. Non-exclusive licenses are licenses given to a number of parties and holders of patent rights still have the right to carry out their patents. Patent Laws have additional confirmation of patents covering the field of technology. Thus, patents are given to inventions or inventions in the field of technology, which after being processed can produce a product or just a process [7]. Means that the understanding of technology here is systematic knowledge, meaning organized and can provide solutions to problems. Patent determines the limitations of inventions that cannot be patented.

The patented inventions are:

a. Products that are announced and their use or implementation is against the rules applicable legislation, religious morality, public order or morality;

b. Theories and methods in the field of science and mathematics;

c. All living things, except microorganisms. 


\section{COMPUTER PROGRAMS THAT ARE REGISTERED IN STATE THE ORIGIN}

Indonesia as one of the signatories to the WTO agreement is required to adjust legal regulations in the IPR field with the approval of TRIPs and various international conventions being a reference, such as the Bern Convention, Rome Convention, Paris Convention, and other conventions under WIPO. Legislation that covers the field of patents is so with the existence of the Patent Law. Besides ratifying the GATT 1994 / WTO, Indonesia has adjusted the legislation related to the international agreement. Among other things, the Patent Cooperation Treaty (Patent CooperationTreaty hereinafter referred to as PCT) Although until now software in general is an object of copyright protection in the state of Indonesia, but the fact that occurs when there is an object of patent protection in another country that has been violated, is still circulating in Indonesia country.

PCT divides patent protection as follows:

A. "national patent" is a patent granted by a National Agency;

B. "regional patents" are patents granted by a National Agency or an Intergovernmental Agency that has power.

C. to give a patent that applies to more than one country; "regional patents" are new and different from the national patent protection at the beginning. So that it is possible for a protected innovation not to be limited to one country but several countries.

Designation of States Parties where protection for the desired invention on the basis of the international patent application can be carried out if for a Designated state a regional patent can be obtained and the applicant wishes to obtain a regional patent rather than a national patent, then this must be stated in the application, and if based on a Treaty on regional patents, the applicant cannot limit his patent application to certain states Parties from the Treaty, then the appointment of one of these countries and instructions on the desire to obtain a regional patent are considered as appointment of all contracting states if, Under the national law of the Designated State, the designation of the country has influence as a request for a regional patent, so the appointment of the country is seen as an indication of the desire to obtain regional patents.

Each resident or citizen of a PCT Member Country can submit an international patent application for the concept of population or citizenship, and the application of these concepts in cases where there are a number of applicants or where the applicantsnot the same for all countries. Designated, explained in the Regulations. 
International patent applications that are different from or which are patches of the provisions of this treaty and its rules

(I) does not affect the application of the provisions of Article 7

(2) and also does not preclude national law from requiring, after the commencement of the process of international patent application at the Designated Office, complete:

(i) if the applicant is a legal entity, the name of a qualified employee representing the legal entity,

(ii) documents that are not part of an international patent application but are alleged evidence or statements of questions made in the patent application, including the ratification of an international patent signed by the applicant when the patent application, as submitted, is signed by representative or proxy. This is in accordance with Article 109 of the Patent Law which justifies the existence of patent applications based on the Patent (PCT) collaborative treaty. PCT is managed by the International Bureau of WIPO, where with one international patent application through one PCT member to get protection in some PCT member countries which means that the international patent application has an effect on regular registration of national patents in each destination country while meeting the registration requirements in the country local including the financing.

The opening of the possibility of registering PCT patents by each party is that it is true that based on the Paris convention (The Paris Convention for Protection of Industrial Property) every country must provide protection and treat industrial property rights of other citizens such as treating its own citizens but on other principles in the convention, member countries are not obliged to grant patents to other citizens.

Applied inventions such as programming languages with algorithms that can be learned in XML registered in US Patents and violated by legal subjects in those countries of origin clearly have an impact on the state of Indonesia which imports a great deal of software, especially Microsoft Office, which is clearly registered and foreign borrowing from the interpretation of international Civil Law elements, the link points contained in xml are nothing but

a. XML is a web derived from SGML (standard Generalized Markup Language) that is found and registered in the US, XML is not a program but is closer to the syntax used to describe other markup languages that have functions such as separating data, defining data roles, defining data boundaries and defines the connection of structured data.

b. Patents on XML have actually been declared violated in the US State

c. The legal consequences of withdrawing all software equipped with the $X M L$ feature are sanctions that have been suffered by the state of Texas

d. There is a legal vacuum of protection against XML even though it is closely related to software, but it is not a software referred to in the Copyright Act in Indonesia

e. Explanation of Article 11 Paragraph 3 of Law Number 11 of 2008 concerning Information and Electronic Transactions In the event that there is no choice of law, the stipulation of applicable law is based on principles or principles of international civil law which will be stipulated as the applicable law on the contract. 


\section{CLOSING}

\subsection{Conclusion}

Until now a computer program, algorithm and programming language such as Extensible MarkupLanguage in a computer program package cannot be an object protected by the Patent Law in Indonesia, based on Article 7 letter $c$ of the Patent Law which states an algorithm that can be qualified as a theory and method in the field science and mathematics cannot be registered through patents, the only protection for XML to be indirectly protected by Patents is through the Patent Cooperation Treaty based on Presidential Decree Number 16 of 1996 where patents can be registered for regional protection of fellow WIPO member countries. extensible markup language feature that has violated patents in the United states in relation to Presidential Decree Number 16 of 1997 in Indonesia does not have executive power to implement the US-Title 35 on Patents, as is the case with the state's limit unless XML has been registered It is possible through PCT that there is patent protection against XML. BY considering priority rights which are limited to retroactive effect when the patent registration is registered for the first time at least in one other country outside Indonesia. 


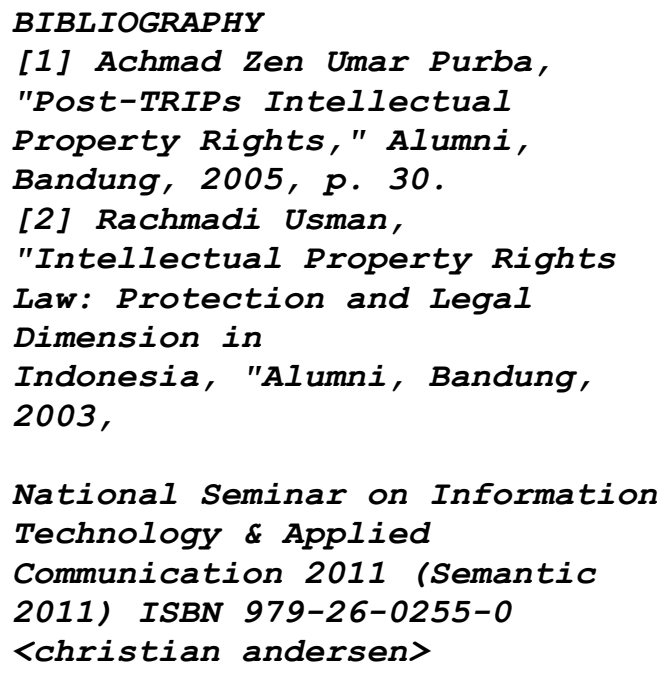

